\title{
Individualization of punishment in the context of the public's fear of crime
}

\author{
Vladimir Pavlovich Konyakhin ${ }^{\square}$, Leonid Aleksandrovich Prokhorov, Marina Leonidovna. \\ Prokhorova, Anton Vladimirovich Petrovskiy, and Ruslan Georgievich Aslanyan \\ Kuban State University, Department of Criminal Law and Criminology, Krasnodar, Russia
}

\begin{abstract}
The individualization of punishment is largely formalized and axiomatically limited by the normative prescriptions of the General and Special parts of the Criminal Code of the Russian Federation. Meanwhile, when assigning punishment, judges always consider all the circumstances related to the commission of a crime and the identity of the perpetrator, not to mention consideration of public opinion, social and group victimization, and the fear of the population before criminal manifestations. Unlike in Russia, the foreign criminal justice system for a long time accepts the opinion of ordinary citizens on this matter, focusing on their fears of separate crimes. Sometimes, within the framework of this system, there is a manipulation of the individualization of punishment to demonstrate a preventive effect to society. Based on the above, this article is aimed at generating a discourse on the need to study and consider victimological information in the formation of criminal law policy in general and the individualization of punishment, in particular. The statistical and sociological research methods used in the study allowed obtaining and summarizing information on the indicators of the fear of residents of Gelendzhik and Novorossiysk (2017-2018) regarding ordinary crimes; reflecting the relationship between these data and the types of punishment imposed by the courts for the commission of theft, robbery, hooliganism. Systemic synthesis and analysis allowed identifying a number of patterns in this area, and justifying them. The novelty of the article is that it represents one of the few attempts to fill the gap in scientific knowledge about the mechanism of individualization of punishment as a tool of social protection, implemented through general and private prevention and requiring consideration of political-social and ethnocultural peculiarities. The results of the study allowed to articulate proposals for optimizing the activities of federal and regional coordinating councils for the prevention of offenses.
\end{abstract}

Keywords: criminal punishment, criminal law, crime prevention, criminology

\section{Introduction}

In the legal doctrine, the individualization of punishment is considered as a principle of criminal responsibility [1]. Despite its apparent simplicity, it is perceived ambiguously by

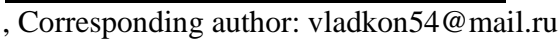


the scientific community, generating acute controversy for a number of reasons: an ambiguous approach to assessing the identity of the guilty person and individual information [2]; ignoring the interests of victims when imposing punishment [3]; the lack of clear criteria for assessing the social danger of the criminal [4]; the lack of interrelation between the intended punishment and value orientations, lifestyle, property status, social role, the social position of the guilty person [5]; formalism with regard to exceptional, mitigating and aggravating circumstances [6].

As for the absolute theory of criminal responsibility, it defines punishment as a tool for managing society, reflecting its legal, ideological, cultural, spiritual, and moral values [7]. The effectiveness of individualization of punishment is seen in achieving effective crime prevention through influencing the will of individuals, coercion, the use of legal restrictions, and social reaction $[8,9]$. Thus, the application of a fair personified punishment generates anti-criminal incentives in society, forms a state of satisfaction with the state, a belief in the inevitability of responsibility, reducing the fear of criminal manifestations.

It should be remembered that judges are specific people who impose punishments with regard to the public danger of the act, the individual characteristics of the guilty person, on the basis of legal awareness and internal conviction. The life positions of judges partly depend on the opinions of other people, who, influencing their psychology, determine the social attitudes of the mentioned category of law enforcement officers and the evaluation criteria used by them. One of the factors influencing the mentality of the judge is the public's fears of crime and individual criminal manifestations [10].

It is important to mention that foreign scientists pay sufficient attention to research on the manifestations of the fear of the population in respect of the most common crimes [11, 12]. The theoretical and practical issues of the correlation between the sensitivity of the community to criminal manifestations and the severity of the criminal justice system are within their view [13]. In Russia, only the feeling of insecurity of the population from social dangers and the impact of the fear of crime on modern society were studied $[14,15]$.

The influence of the population's fear of crime on the process of sentencing is a new direction for Russian criminal law science. Therefore, a hypothesis should be verified: does the judicial discretion in Russia affect the fear of people before criminal manifestations.

Thus, in this article, by studying the relationship between the types of punishment imposed by the courts for the commission of theft, robbery, hooliganism, and the fear of the population before such criminal manifestations, the interaction of social expectations with law enforcement practice was tested.

To implement this task, the following has been studied: the frequency of criminal events in the lives of residents of the cities of Gelendzhik and Novorossiysk; the opinion about security at the place of their residence; awareness of the most common criminal threats; the ratio of convicts to imprisonment, and to other types of punishment. This made allowed to articulate the relevant proposals of a doctrinal and applied nature.

\section{Methods}

When writing the article, statistical methods of systematization and analysis of the aggregate of statistical indicators of criminal records in the Krasnodar Territory in 2017-2019 were used. To obtain information about the fears of the population of the Krasnodar Territory of criminal manifestations, the questionnaire method was used, information was obtained from 600 respondents in Gelendzhik $(2017, \mathrm{n}=355)$ and Novorossiysk $(2018, \mathrm{n}=245)$. As an independent indicator of fear, the opinion of citizens about: 1) the frequency of criminal events in their lives; 2) the security in their place of residence; 3) the fear of the population of crimes that they may encounter in life was established [16]. 


\section{$3 \quad$ Results}

Table 1. Frequency of criminal events in the life of the population (\%).

\begin{tabular}{|l|c|c|c|c|}
\hline Criminal events & often & sometimes & rarely & never \\
\hline $\begin{array}{l}\text { Verbal conflict with violence between } \\
\text { neighbors }\end{array}$ & 13.2 & 23.7 & 13.2 & 50.0 \\
\hline Fighting with weapons & 3.9 & 11.1 & 5.6 & 79.4 \\
\hline Robbery or street robbery & 2.6 & 13.7 & 7.9 & 65.8 \\
\hline $\begin{array}{l}\text { Theft of property with penetration into } \\
\text { the hone }\end{array}$ & 13.2 & 11.5 & 23.7 & 51.6 \\
\hline Theft of property from a car & 5.3 & 20.9 & 26.3 & 47.4 \\
\hline
\end{tabular}

Table 2. Public opinion on the security of the place of residence (\%).

\begin{tabular}{|l|c|c|c|c|}
\hline Criminal threats & Totally unsafe & Unsafe & Safe & Completely safe \\
\hline Leave the house in the dark & 5.3 & 44.7 & 42.1 & 7.9 \\
\hline $\begin{array}{l}\text { Walk along unfamiliar roads or } \\
\text { through wastelands }\end{array}$ & 23.7 & 39.5 & 21.1 & 15.8 \\
\hline Use public transport in the dark & 10.5 & 18.4 & 52.6 & 18.6 \\
\hline Carry a large amount of money & 21.1 & 31.6 & 21.1 & 26.3 \\
\hline $\begin{array}{l}\text { Stay at night in public places: } \\
\text { cinemas, parks, streets, squares }\end{array}$ & 2.6 & 28.9 & 52.6 & 15.8 \\
\hline
\end{tabular}

Table 3. Population's estimation of the most common criminal threats (\%).

\begin{tabular}{|l|c|c|c|}
\hline Criminal risks & All the time & Sometimes & Never \\
\hline Theft & 10.2 & 36.6 & 53.2 \\
\hline Robbery & 4.5 & 24.7 & 70.5 \\
\hline Intentional infliction of harm to health & 3.1 & 19.6 & 77.0 \\
\hline Hooliganism & 5.4 & 29.3 & 65.3 \\
\hline Kidnappingman & 3.4 & 16.8 & 79.8 \\
\hline Rape & 2.3 & 12.8 & 84.9 \\
\hline Murder & 4.3 & 9.7 & 86.1 \\
\hline Terrorist act & 4.3 & 16.5 & 79.3 \\
\hline
\end{tabular}

Table 4. Ratio of convicts for theft, robbery, hooliganism to imprisonment, and other types of punishment (\%).

\begin{tabular}{|l|l|c|c|c|}
\hline Crimes & Types of punishments & $\mathbf{2 0 1 7}$ & $\mathbf{2 0 1 8}$ & $\mathbf{2 0 1 9}$ \\
\hline \multirow{4}{*}{ theft } & deprivation of liberty & 33.0 & 33.3 & 33.2 \\
\cline { 2 - 5 } & conditional imprisonment & 33.4 & 32.9 & 34.5 \\
\cline { 2 - 5 } & correctional labor and fine & 15.2 & 14.8 & 14.4 \\
\cline { 2 - 5 } & other types of punishment & 18.4 & 19 & 17.9 \\
\hline \multirow{4}{*}{ robbery } & deprivation of liberty & 49.3 & 50.2 & 49.7 \\
\cline { 2 - 5 } & conditional imprisonment & 15.5 & 15.5 & 15.3 \\
\cline { 2 - 5 } & Correctional labor and fine & 3.3 & 3.2 & 3.3 \\
\cline { 2 - 5 } & Other types of punishments & 31.9 & 31.0 & 31.6 \\
\hline \multirow{2}{*}{ hooliganism } & deprivation of liberty & 25.9 & 27.9 & 26.2 \\
\cline { 2 - 5 } & Other types of punishment & 74.1 & 72.1 & 73.8 \\
\hline
\end{tabular}

\section{Discussion}

After analyzing the results of interviews with residents of the cities of Gelendzhik and Novorossiysk, the following trends could be established: 
- most often in the life of respondents - 36.9\% - there are verbal conflicts with violence between neighbors, which can be qualified as hooliganism, theft with home invasion $-26.4 \%$ and theft from vehicles $-26.2 \%$;

- the greatest fears are caused by the need to leave the house at night - in $50 \%$ of respondents; to carry a large amount of money - in 52.7\%; to walk on unfamiliar roads or through wastelands - in $63.2 \%$;

- $46.8 \%$ of respondents believe that they are most likely to become a victim of theft $46.8 \%$, hooliganism $-34.7 \%$, robbery $-29.2 \%$.

The system of criminal justice reacts to such criminal manifestations as theft, robbery, and hooliganism as follows. For the commission of thefts, an average of $33.1 \%$ is sentenced to imprisonment related to their actual service; $76.9 \%$ are sentenced to other types of punishment not related to isolation from society. For committing robberies, $49.7 \%$ are sentenced to actual imprisonment; $50.2 \%$ remain at large and are under the supervision of the criminal executive inspections. Only $26.6 \%$ of those who commit hooliganism are sentenced to imprisonment, and they are sent to correctional and educational institutions.

Thus, it is obvious that, in general, the fears and anxious expectations of the population are not groundless. The point is the Russian criminal justice system does not consider the victimological component of a crime, ignoring the fears of citizens before certain criminal manifestations. This influences the assessment of the effectiveness of law enforcement agencies, causes distrust among the population to the state authorities. Oppositely, law enforcement and judicial authorities of foreign states, following the principle of pragmatism, consider the results of victimological surveys that are implemented in criminal law policy [17]. This creates a desire among the population to interact with the police, to participate in ensuring public order and activities to prevent offenses at the municipal level.

\section{Conclusion}

Public opinion in the part of the fears experienced by residents of municipalities before crime should be used in the implementation of both criminal and criminological policy. Following Federal Law No. 182-FZ dd. June 23, 2016, law enforcement agencies and regional authorities shall establish a coordinating body for the prevention of offenses in each constituent entity of the RF. For more effective cooperation, given that criminal punishment is an effective tool for preventing crimes, it is necessary to involve representatives of the regional judicial authorities in the activities of the coordinating body.

Each of the prevention actors shall once a year monitor the causes and conditions of crime and the effectiveness of measures to counteract it. One of the purposes of monitoring should be to obtain information about the fears of the population before criminal manifestations and the probabilistic expectations of a citizen to become a victim of criminal encroachment. This information can be used both for planning preventive measures and by the heads of regional judicial bodies to unify the approach to the imposition of criminal penalties.

\section{References}

1. K.A. Ainutdinova, Kriterii individualizatsii ugolovnogo nakazaniya pri ego naznachenii v teorii, zakonodatelstve i sudebnoi praktike [Criteria for individualization of criminal punishment in its appointment in theory, legislation, and judicial practice], $\mathrm{PhD}$ thesis (Kazan, 2017)

2. V.N. Burlakov, Individualizatsiya ugolovnogo nakazaniya: zakon, teoriya, sudebnaya praktika [Individualization of criminal punishment: law, theory, judicial practice], Educational and practical guide (Yuridicheskii Tsentr Press, Saint Petersburg, 2011) 
3. M.S. Dikaeva, Ugolovnoe nakazanie v Rossii i zarubezhnykh stranakh:

kriminologicheskii analiz [Criminal punishment in Russia and foreign countries:

criminological analysis] (Yurlitinform, Moscow, 2017)

4. S.F. Milyukov, Criminology: Yesterday, Today, Tomorrow, 2(45), 26-29 (2017)

5. E.R. Azaryan, Prestuplenie. Nakazanie. Pravoporyadok [Crime. Punishment. Law and Order] (Yuridicheskii Tsentr Press, Saint Petersburg, 2004)

6. V.N. Voronin, Individualizatsiya nakazaniya: ponyatie, kriterii, znachenie. [Individualization of punishment: concept, criteria, meaning], $\mathrm{PhD}$ thesis (Moscow, 2015)

7. M. Foucault, Nadzirat i nakazyvat. Rozhdenie tyurmy [Discipline and Punish: The Birth of the Prison] (Ad Marginem, Moscow, 2015)

8. G.N. Gorshenkov, Criminology: Yesterday, Today, Tomorrow, 2(45), 19-25 (2017)

9. I.M. Ragimov, O nravstvennosti nakazaniya [On the morality of punishment] (Yuridicheskii Tsentr Press, Saint Petersburg, 2016)

10. O.R. Afanasyeva, P.B. Afanasyev, Bul. Acad. Law and Manag. 1(50), 33-39 (2018)

11. A.L. Gurinskaya, Anglo-amerikanskaya model preduprezhdeniya prestupnosti: kriticheskii analiz [The Anglo-American model of crime prevention: a critical analysis] (Izdatelstvo RGPU im. A. I. Gertsena, Saint Petersburg, 2018)

12. V. Ceccato, J. Assiago, M.K. Nalla, Crime and Fear in Public Places. In Crime and Fear in Public Places: Towards safe, Inclusive and Sustainable Cities (Routledge, London, 2020). https://doi.org/10.4324/9780429352775

13. D.M. Reynald, J. Contemp. Crim. Just. 31(1), $71-89$ (2015)

14. V.G. Nemirovskiy, A.V. Nemirovskaya, Monit. Pub. Op. 1(107), 113-127 (2012)

15. A.V. Romanova, Sotsialnye posledstviya strakha pered prestupnostyu v sovremennom obshchestve [Social consequences of fear of crime in modern society], $\mathrm{PhD}$ thesis (Vladivostok, 2005)

16. K. Eman, B. Lobnikar, A. Petrovskiy, G. Meško, Criminal Justice and Security in Central and Eastern Europe, 485-496 (2018). https:doi.org/10.18690/978-961-286-1742.39

17. J. Lane, N. Rader, B. Henson, B.S. Fisher, D.C. May, Fear of Crime in the United States: Causes, Consequences, and Contradictions (Carolina Academic Press, Durham, NC, 2014) 